\title{
Transcriptional and biochemical biomarker responses in a freshwater mussel (Anodonta anatina) under environmentally relevant $\mathrm{Cu}$ exposure
}

\author{
Gustaf Magnus Oskar Ekelund Ugge $^{1,2}\left[\right.$ (D) Annie Jonsson ${ }^{2} \cdot$ Björn Olsson $^{2} \cdot$ Robert Sjöback $^{3} \cdot$ Olof Berglund $^{1}$
}

Received: 1 November 2019 / Accepted: 7 January 2020 / Published online: 13 January 2020

(C) The Author(s) 2020

\begin{abstract}
Molecular biomarkers, like gene transcripts or enzyme activities, are potentially powerful tools for early warning assessment of pollution. However, a thorough understanding of response and baseline variation is required to distinguish actual effects from pollution. Here, we assess the freshwater mussel Anodonta anatina as a biomarker model species for freshwater ecosystems, by testing responses of six transcriptional (cat, gst, hsp 70, hsp90, $m t$, and sod) and two biochemical (AChE and GST) biomarkers to environmentally relevant $\mathrm{Cu}$ water concentrations. Mussels $(n=20)$, collected from a stream free from point source pollution, were exposed in the laboratory, for $96 \mathrm{~h}$, to $\mathrm{Cu}$ treatments $(<0.2 \mu \mathrm{g} / \mathrm{L}, 0.77 \pm 0.87 \mu \mathrm{g} / \mathrm{L}$, and $6.3 \pm 5.4 \mu \mathrm{g} / \mathrm{L})$. Gills and digestive glands were extracted and analyzed for transcriptional and biochemical responses. Biological and statistical effect sizes from $\mathrm{Cu}$ treatments were in general small (mean $\log _{2}$ fold-change $\leq 0.80$ and Cohen's $f \leq 0.69$, respectively), and no significant treatment effects were observed. In contrast, four out of eight biomarkers (cat, gst, hsp 70, and GST) showed a significant sex:tissue interaction, and additionally one ( $s o d)$ showed significant overall effects from sex. Specifically, three markers in gills ( $c a t, m t$, GST) and one in digestive gland (AChE) displayed significant sex differences, independent of treatment. Results suggest that sex or tissue effects might obscure low-magnitude biomarker responses and potential early warnings. Thus, variation in biomarker baselines and response patterns needs to be further addressed for the future use of $A$. anatina as a biomarker model species.
\end{abstract}

Keywords Bivalve $\cdot$ Gene expression $\cdot$ Response variability $\cdot$ Sex effects $\cdot$ Effect size $\cdot$ RT-qPCR

\section{Introduction}

High-resolution quantification of early molecular responses to environmental stress is recently made possible by rapid advances within omics technology. Transcriptomics can potentially be

Responsible editor: Philippe Garrigues

Electronic supplementary material The online version of this article (https://doi.org/10.1007/s11356-020-07660-4) contains supplementary material, which is available to authorized users.

Gustaf Magnus Oskar Ekelund Ugge

gustaf.ekelund_ugge@biol.lu.se

1 Department of Biology, Lund University, Sölvegatan 37, 223 62 Lund, Sweden

2 School of Bioscience, University of Skövde, Högskolevägen 3, 541 28 Skövde, Sweden

3 TATAA Biocenter, Odinsgatan 28, 41103 Gothenburg, Sweden used to find biomarkers for pollution; however, gene expression is challenging to relate to whole-organism, population, or ecosystem effects. In contrast, standardized single endpoint ecotoxicity tests, such as mortality and inhibition of growth rate or reproduction (e.g., Organisation for Economic Co-operation and Development 1992, 2004, 2006, 2012), give useful insight into toxic potency of pollutants, but without giving early warnings (Connon et al. 2012). Ideally, molecular responses would be extrapolated to predict effects on higher biological levels. The link is however complicated by a lacking understanding of how baseline gene expression patterns vary with, for example, species, sexes, developmental stages, and seasons (Bahamonde et al. 2016; Fent and Sumpter 2011). Although not always addressed, understanding the variation is thus necessary to discern actual responses from the background noise, for meaningful interpretation of transcriptional data and for successful integration into molecular biomarker panels (Bahamonde et al. 2016). In this study, we have taken initial steps to address baseline and response variation of transcriptional and biochemical biomarkers within and between tissues, sexes, and treatments of a potential 
model species, the duck mussel (Anodonta anatina, family Unionoida).

In ecological monitoring, bivalves are commonly used as bioindicators of aquatic pollution, and various species have been used as model organisms for transcriptional biomarkers in laboratory and field studies (Bigot et al. 2011; GonzalesRey et al. 2014; Jaumot et al. 2015; Liu et al. 2014, 2016; Navarro et al. 2011). Mytilus sp. is a frequent bivalve model in marine monitoring, and the zebra mussel (Dreissena polymorpha) has been proposed as a potential freshwater counterpart (Binelli et al. 2015). However, the zebra mussel is invasive to many Scandinavian and European freshwater systems, which makes us suggest a naturally occurring species, A. anatina, as a safer and more ecologically relevant model candidate for field and laboratory studies. This species is widely distributed in Sweden as well as across large parts of Europe (Lopes-Lima 2014). Research on A. anatina has to date mostly focused on its phylogeny, morphology, reproduction, and seasonal behavior (Aldridge 1999; Jonsson et al. 2013; Lurman et al. 2014). A. anatina and other unionid mussels undergo a complex lifecycle, where gravid females brood eggs and larvae (glochidia) in their gills until parasitic glochidia are released to mature in the gills of host fish (Aldridge 1999; Barnhart et al. 2008; Hinzmann et al. 2013). A. anatina has already been used as a model in ecotoxicological field and laboratory studies (Bielen et al. 2016; Falfushynska et al. 2013, 2014; Hartmann et al. 2016; Nugroho and Frank 2011, 2012a, b; Oliviera et al. 2015; Santini et al. 2011), but to our knowledge, transcriptional biomarkers have not previously been studied in the species.

As a primary step to test the potential of A. anatina as a model species for molecular biomarkers, we quantified six transcriptional biomarkers after chemical stress. The genes were catalase (cat), glutathione-S-transferase ( $g s t)$, heat shock proteins 70 and 90 ( $h s p 70$ and $h s p 90$, respectively), metallothionein $(m t)$, and superoxide dismutase (sod). Catalase and superoxide dismutase are enzymes involved in cellular defense against reactive oxygen species (Bigot et al. 2011; Boukadida et al. 2017), whereas metallothionein plays a main role in metal homeostasis (Fabisiak et al. 1999). Heat shock proteins are involved in general cellular stress response (Liu et al. 2014, 2016) and glutathione-S-transferase in pollutant detoxification (Canesi et al. 1999). As a complement to the transcriptional biomarkers, enzymatic activity of glutathioneS-transferase (GST) was measured in addition to its transcription. Finally, enzymatic activity of acetylcholinesterase (AChE), an enzyme crucial to regulation of nerve signaling (Bocquené and Galgani 1998), was also assessed.

In order to elicit stress responses, $\mathrm{Cu}$ was chosen as our experimental model toxicant. In pristine freshwater systems, $\mathrm{Cu}$ concentrations are often in the nanogram per liter range (Álvarez-Vázquez et al. 2017; Sander et al. 2013; Vukosav et al. 2014), while in urbanized and polluted areas, in the microgram per liter range (Álvarez-Vázquez et al. 2017; Bhuiyan et al. 2015; Wilson and McMahon 1981), approaching the milligram per liter range in heavily polluted areas (Bhuiyan et al. 2015). According to Swedish environmental quality standards, an annual mean concentration of $\leq$ $0.5 \mu \mathrm{g}$ bioavailable $\mathrm{Cu} / \mathrm{L}$ is required for a "good" status classification (Havs- och vattenmyndigheten 2018). In the current experiment, responses of wild-caught mussels were assessed after exposure to an environmentally relevant range of sublethal $\mathrm{Cu}$ levels (additions of $1-100 \mu \mathrm{g} / \mathrm{L}$ ) in the laboratory. The a priori hypotheses were that (1) biomarkers respond within the range of $\mathrm{Cu}$ concentrations (different relative expressions or activities as compared to the control treatment) and (2) relative response magnitudes differ between treatments and between tissues (gill and digestive gland). In addition to treatment and tissue, mussel sex was included in the model when it became apparent that gravidness affected certain biomarkers.

\section{Material and methods}

\section{Biomarkers}

Six transcriptional (cat, gst, hsp 70, hsp90, $m t$, sod) and two biochemical (AChE, GST) responses were analyzed by reverse transcription quantitative polymerase chain reaction (qPCR) and enzymatic activity assays, respectively. Stress gene selection was based on biomarkers previously used to assess chemical stress in laboratory and field studies on bivalves (Bigot et al. 2011; Gonzales-Rey et al. 2014; Jaumot et al. 2015; Liu et al. 2014, 2016; Navarro et al. 2011). AlleleID software (Premier Biosoft, USA) was used for primer design, based on homologous sequences found using the NCBI nucleotide search function (Table A.1). For each gene used, sequences were found for a minimum of one unionid mussel species (order Unionoida) and a minimum of four bivalve species in total. Actual sequences from Anodonta anatina were only found and used for primer design for the 28S rRNA gene. The two biochemical markers, AChE and GST, have both been previously used in mussel gills and digestive glands (Lehtonen et al. 2016).

\section{Mussel collection and maintenance}

On the 13th of October 2017, 20 mussels (species Anodonta anatina, $83 \pm 13 \mathrm{~mm}$ shell length) were collected in Vinne å (southern Sweden, $56^{\circ} 06^{\prime} 45^{\prime \prime} \mathrm{N}, 13^{\circ} 54^{\prime} 35^{\prime \prime} \mathrm{E}$ ), a freshwater stream with no known point source pollution. Before the start of experiments, the mussels were acclimatized to laboratory conditions for 14 days. During this period, mussels were kept in a $60-\mathrm{L}$ glass aquarium, with $30 \mathrm{~L}$ reconstituted freshwater (International organization for standardization 2012), hereafter referred to as freshwater medium, used as medium. The 
freshwater medium was prepared from distilled water with additions of $294 \mathrm{mg} / \mathrm{L} \mathrm{CaCl} 2 \cdot 2 \mathrm{H}_{2} \mathrm{O}, 123.3 \mathrm{mg} / \mathrm{L} \mathrm{MgSO}_{4}$. $7 \mathrm{H}_{2} \mathrm{O}, 64.8 \mathrm{mg} / \mathrm{L} \mathrm{NaHCO}_{3}$, and $5.8 \mathrm{mg} / \mathrm{L} \mathrm{KCl}$ (laboratory reagent grade, Scharlau) and had a nominal hardness of $250 \mathrm{mg} / \mathrm{L} \mathrm{CaCO}_{3}$. A 5-cm siliceous sand layer was added as bottom substrate to the aquarium. The sand ("Blästersand," batch 07/17, purchased from Brogård Sand AB, Sweden) originated from Lake Vättern, Sweden, and had a grain size of $0.2-$ $0.7 \mathrm{~mm}$. Before use, the sand was thoroughly washed by hand, by repeatedly stirring it under tap water until the runoff water was clear, and subsequently rinsed with distilled water before added to the aquarium. During acclimatization, the medium was continuously aerated, and three times weekly, 10-20 L medium was renewed. At each time of medium renewal, mussels were fed by additions of Pseudokirchneriella subcapitata corresponding to approximately $8 \times 10^{5}$ cells mussel $^{-1}$ day $^{-1}$, except for $48 \mathrm{~h}$ before the start of the experiments, during which mussels were starved. During acclimatization, water temperature ranged between 16 and $20^{\circ} \mathrm{C}$, and the light cycle was 16-h light:8-h dark.

\section{Experimental treatments}

$\mathrm{A} \mathrm{Cu}$ stock solution was prepared from $\mathrm{CuCl}_{2} \cdot 2 \mathrm{H}_{2} \mathrm{O}$ (laboratory reagent grade, Fisher Scientific) diluted in freshwater medium to a nominal concentration of $100 \mathrm{mg} / \mathrm{L}$. Stock solution was diluted with freshwater medium in preparation of the three exposure media, to nominal $\mathrm{Cu}$ water concentrations of 1,10 , and $100 \mu \mathrm{g} / \mathrm{L}$, respectively. Freshwater medium without $\mathrm{Cu}$ was used for control treatments. One hundred micrograms per liter was selected as the highest concentration in order not to impact filtration and, thus, $\mathrm{Cu}$ uptake, based on a previous preliminary $\mathrm{Cu}$ exposure experiment with identical setup. In the pre-experiment, prolonged shell closure was observed at additions of $200 \mu \mathrm{g} \mathrm{Cu} / \mathrm{L}$. Glass aquaria with $4.5 \mathrm{~L}$ continuously aerated exposure medium and a 5-cm sand layer, prepared as previously described, were prepared approximately $48 \mathrm{~h}$ prior to the experimental start. Water (unfiltered) for determination of total $\mathrm{Cu}$ concentration was sampled in experimental aquaria at the experiment start, as well as in Vinne å at five time points during December 2017 to December 2018. In addition, the $\mathrm{Cu}$ stock solution was sampled. Samples were frozen and subsequently acidified with $1 \%(\mathrm{v} / \mathrm{v}) \mathrm{HNO}_{3}$ before $\mathrm{Cu}$ determination. Total $\mathrm{Cu}$ concentrations in water samples were measured by ICP-MS (Aurora Elite, Bruker Daltonics, Germany) for experimental treatments and environmental samples, and by ICP-OES (Optima 8300, Perkin Elmer, USA) for the stock solution, respectively. Measured $\mathrm{Cu}$ concentrations were $<0.2 \mu \mathrm{g} / \mathrm{L}$ both in the control treatment and after $1 \mu \mathrm{g} / \mathrm{L}$ addition, and on average $0.77 \pm 0.87 \mu \mathrm{g} / \mathrm{L}$ and $6.3 \pm 5.4 \mu \mathrm{g} / \mathrm{L}$ after addition of $10 \mu \mathrm{g} / \mathrm{L}$ and $100 \mu \mathrm{g} / \mathrm{L}$, respectively (Table A.2). Estimated $\mathrm{Cu}$ sand/ water partition coefficients $\left(K_{d}\right)$ were 84 and $110 \mathrm{~L} / \mathrm{kg}$ for the 10 and $100 \mu \mathrm{g} \mathrm{Cu} / \mathrm{L}$ additions, respectively (Table A.2). The $\mathrm{Cu}$ concentration of the stock solution was $66 \mathrm{mg} / \mathrm{L}$, and sampled background levels in Vinne å ranged between 0.080 and $0.71 \mu \mathrm{g}$ $\mathrm{Cu} / \mathrm{L}$ over time (Table A.2).

Mussels were treated in individual aquaria and fed daily with $P$. subcapitata solution (approximately $8 \times$ $10^{5}$ cells day $^{-1}$ ). During the experiment, medium temperature was $15 \pm 1^{\circ} \mathrm{C}$ and the light cycle was 16-h light:8-h dark. After $48 \mathrm{~h}, 1.5-\mathrm{L}$ medium was renewed in each aquarium, and after $96 \mathrm{~h}$, the exposure was interrupted and mussels were immediately dissected. Gills and digestive glands were extracted and snap frozen in liquid nitrogen. Tissues were stored at $-80^{\circ} \mathrm{C}$ until RNA extraction and again until cytosol extraction for biochemical assays. The extractions were made from frozen tissue, and samples were not allowed to thaw in between. During dissection, gravid mussels (hereafter referred to simply as females) were distinguished visually by the presence of eggs or glochidia in the gills (Aldridge 1999; Hinzmann et al. 2013). Male:female sex distribution across treatments was 1:4, 2:3, $3: 2$, and $3: 2$ in control, 1,10 , and $100 \mu \mathrm{g} \mathrm{Cu} / \mathrm{L}$, respectively. Upon snap freezing, one female gill sample was lost from each treatment group, i.e., $n=4$ per treatment remaining for gills.

After biomarker analyses, $\mathrm{Cu}$ concentration in remaining tissue samples (16 gill and 14 digestive gland samples, respectively) was analyzed by ICP-SFMS (Element XR, Thermo Scientific, Germany) according to Engström et al. (2004). Bioconcentration factors (BCFs) were estimated for each tissue sample where corresponding water concentration was determined ( $>$ LOQ).

$$
B C F=\frac{\text { Tissue concentration }(\mu \mathrm{g} / \mathrm{kg} \mathrm{WW})}{\text { Water concentration }(\mu \mathrm{g} / \mathrm{L})}
$$

\section{Gene expression}

RNA was extracted from each sample, followed by reverse transcription synthesis of cDNA, which was in turned used in qPCR assays. RNA was extracted from gill and digestive gland samples by using the SurePrep ${ }^{\mathrm{TM}}$ TrueTotal ${ }^{\mathrm{TM}}$ RNA Purification Kit (Fisher Scientific, USA). The A260/A280 ratio was checked using a NanoVue ${ }^{\mathrm{TM}}$ Plus (GE Healthcare, USA) and was 1.92.1 in extracted samples. RNA integrity was assessed qualitatively by gel electrophoresis on $1 \%$ agarose gels, and a subset of samples underwent RNA quality assessment using Fragment Analyzer (Advanced Analytical, Austria). Based on qualitative and quantitative integrity assessments, all samples were assumed to have an RQN (RNA quality number) of $\geq 6$.

For each sample, $1 \mu \mathrm{g}$ of RNA was converted to cDNA by reverse transcription, using the Verso cDNA Synthesis Kit (Thermo Scientific, USA), with random hexamer primers and a reaction cycle of $42^{\circ} \mathrm{C}$ for $60 \mathrm{~min}, 95{ }^{\circ} \mathrm{C}$ for $2 \mathrm{~min}$, and $4{ }^{\circ} \mathrm{C}$ for $2 \mathrm{~min}$. qPCR assays were performed using TATA A SYBR ${ }^{\circledR}$ GrandMaster ${ }^{\circledR}$ Mix (TATAA Biocenter, Sweden), 
and $400 \mathrm{nM}$ of the respective primer pair, on a $C F X 384^{\mathrm{TM}}$ Real-Time PCR Detection System (Bio-Rad, USA). The reaction program consisted of polymerase activation at $95{ }^{\circ} \mathrm{C}$ for $60 \mathrm{~s}$, then 45 cycles of denaturation $\left(95^{\circ} \mathrm{C}\right.$ for $\left.5 \mathrm{~s}\right)$, annealing $\left(58^{\circ} \mathrm{C}\right.$ for $\left.30 \mathrm{~s}\right)$, and extension $\left(72^{\circ} \mathrm{C}\right.$ for $\left.10 \mathrm{~s}\right)$. A dissociation curve (from $60^{\circ}$ to $95^{\circ} \mathrm{C}$ ) finalized the program. Primers were purchased from Integrated DNA Technologies (Belgium).

Assay efficiencies were estimated from dilution series of pooled samples. Efficiency determination was performed on a StepOnePlus ${ }^{\mathrm{TM}}$ (Applied Biosystems, USA), using Maxima SYBR Green/ROX qPCR Master Mix (Thermo Scientific, USA) for the reactions. Estimated efficiencies were 96-102\% (Table A.1), and a $100 \%$ efficiency was assumed for all assays. Relative gene expression was determined by the $2^{-\Delta \Delta \mathrm{Ct}}$ method (Livak and Schmittgen 2001), normalizing expression by the mean expression of control samples of gill and digestive gland tissue, respectively. The mean of two reference genes, $\beta$-actin and $28 \mathrm{~S}$ rRNA, was used for within-sample normalization.

\section{Enzyme activity}

AChE and GST activity assays were modified from Bocquené and Galgani (1998) and Habig et al. (1974), respectively. Tissue samples were mechanically homogenized on ice in 5:1 (v:w) $0.02 \mathrm{M} \mathrm{Na}_{2} \mathrm{HPO}_{4} / \mathrm{KH}_{2} \mathrm{PO}_{4}$ buffer ( $0.1 \%$ Triton-X, $\mathrm{pH}$ 7.4) for AChE assays and in 4:1 (v:w) $0.1 \mathrm{M} \mathrm{KH}_{2} \mathrm{PO}_{4}$ buffer ( $\mathrm{pH}$ 7.4) for GST assays. Following homogenization, samples were centrifuged at $10,000 \mathrm{~g}\left(4{ }^{\circ} \mathrm{C}, 20 \mathrm{~min}\right)$, and supernatants were stored at $-80^{\circ}$ until analysis. Activities were measured for spectrophotometrically at $412 \mathrm{~nm}$ for $5 \mathrm{~min}$ and $350 \mathrm{~nm}$ for $2 \mathrm{~min}$, for AChE and GST respectively. Assays were performed in 96-well microplates (Nunc, Denmark), and absorbance measured using a SpectraMax 190 plate reader (Molecular Devices, USA). AChE activity was expressed as the hydrolysis rate of acetylthiocholine (Bocquené and Galgani 1998), whereas GST activity was expressed as the rate of glutathione conjugation to 1-chloro-2,4-dinitrobenzene (Habig et al. 1974). Finally, enzymatic activities were normalized by the protein concentration from each extracted tissue sample, as determined by the Bradford (1976) method, using a bovine serum albumin standard curve.

\section{Statistics}

Statistical analyses were run and figures were generated in $\mathrm{R}$ version 3.5.2 (R Core team 2018). Measured tissue concentrations were compared between treatment groups by ANOVA. Concentration dependence of tissue $\mathrm{Cu}$ concentrations was tested by correlation (Pearson) to measured $\mathrm{Cu}$ concentration in the exposure medium. Both concentrations were $\log _{10^{-}}$ transformed, and samples corresponding to water levels below LOQ were excluded. Gene expressions and enzyme activities were normalized relative to the mean of the respective tissue in the control group and then $\log _{2}$-transformed. Transformed values are hereafter referred to as responses and were visualized by principal component analysis, using the $\mathrm{R}$ package "factoextra" (Kassambara and Mundt 2017). Responses were then analyzed in a linear mixed model, using the R package "Ime4" (Bates et al. 2015). Response was used as the dependent variable for each marker, and full models included the fixed effect terms treatment, sex, and tissue, as well as their interactions (Table A.3). Mussel ID was used as a random effect. Model selection was performed by sequential type I ANOVA analysis, where insignificant effect factors were removed one at a time until remaining factors and/or interactions were significant $(p<0.05)$. For biomarkers where the mixed model selection resulted in a singular fit, the tissues were instead analyzed by separate linear models. Residual normality for biomarker responses and tissue $\mathrm{Cu}$ concentrations was assessed by Shapiro-Wilk normality tests and $Q-Q$ plots. Significant differences in the final models were identified with a Tukey HSD post hoc test, using the "emmeans" package (Lenth 2018). Finally, the R package "simr" (Green and MacLeod 2016) was used for power analysis by simulation in the linear mixed models, while the packages " $p w r$ " (Champely 2018) and "sjstats" (Lüdecke 2018) were used for power analysis and effect size assessment of ANOVAs.

\section{Results}

Treatment groups did not differ significantly in measured tissue concentration in either gills or digestive glands $(p>0.05)$, despite gills demonstrating an approximately twofold higher mean concentration in the $100 \mu \mathrm{g} / \mathrm{L}$ group as compared to control (Fig. 1). Yet, the gill $\mathrm{Cu}$ concentrations were significantly correlated with measured water $\mathrm{Cu}$ concentrations (Fig. 1). In contrast, digestive gland $\mathrm{Cu}$ concentrations were not correlated with exposure levels (Fig. 1). Across exposures in which water $\mathrm{Cu}$ was $>$ LOQ, median BCF was $3400 \mathrm{~L} / \mathrm{kg} \mathrm{WW}$ and $1500 \mathrm{~L} / \mathrm{kg} \mathrm{WW}$ in gills and digestive gland, respectively.

Overall, sex and tissue effects and/or interactions were prominent for all biomarkers except $h s p 90$. No distinct responses from $\mathrm{Cu}$ treatments were demonstrated. Biomarker responses showed overlapping distributions in all experimental treatments, and no biomarker showed discernable differences between treatment groups, neither in gills nor in digestive glands (Figs. 2 and 3). Gill responses generally showed higher variation for all markers except $g s t$ and $h s p 90$. Standard deviations of $m t$, AChE, and GST were consistently greater in gills than in digestive glands across treatments (Table A.4). For $m t$ and GST, overall standard deviation in gills was more than twice the size of that in digestive glands. Similarly, no treatment effects could be inferred from principal component analysis of biomarker responses separated by tissue (Figs. 4 and 5). In gills however, there was a separation of 

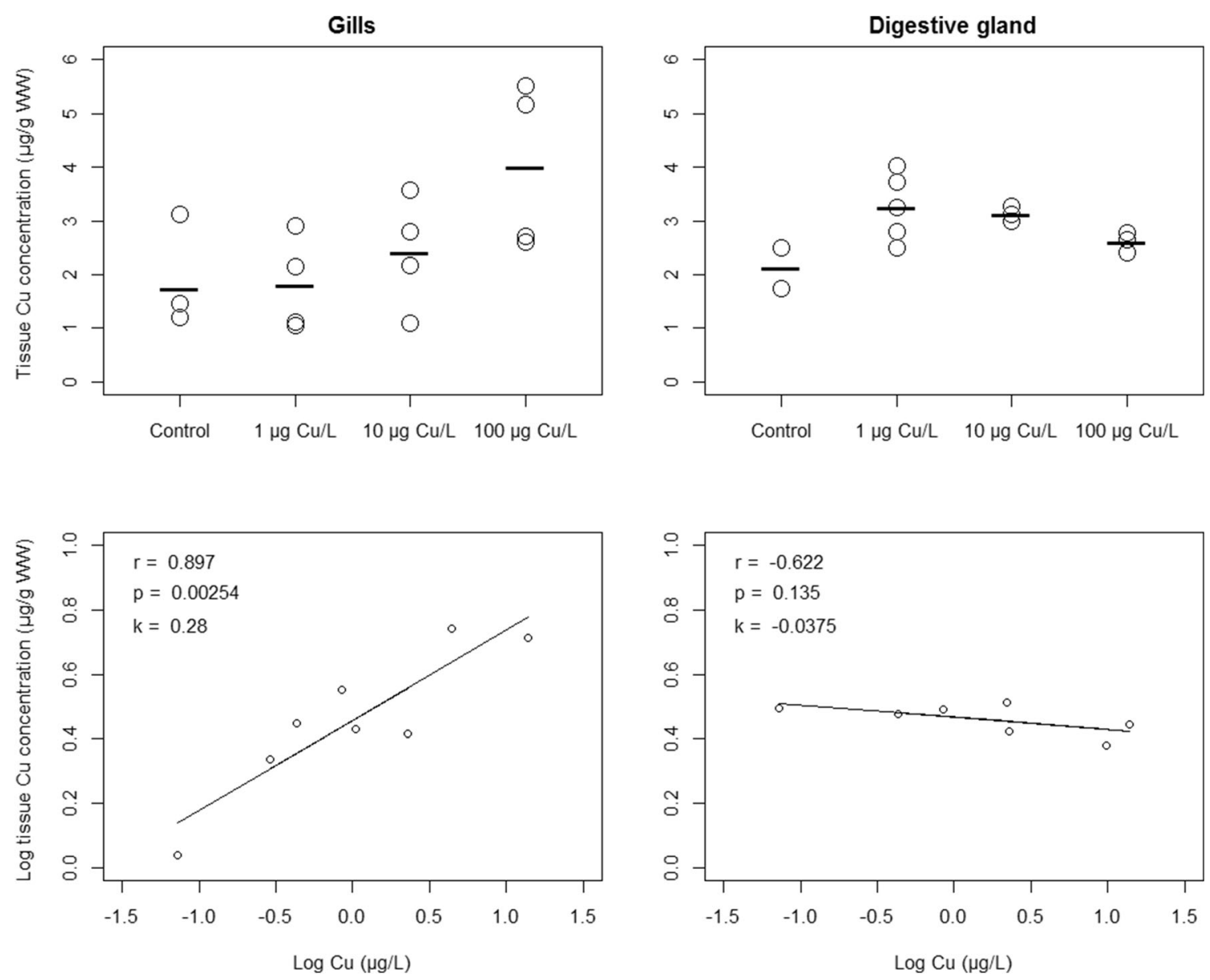

Fig. $1 \mathrm{Cu}$ concentration $(\mu \mathrm{g} / \mathrm{g} \mathrm{WW})$ in gill (upper left) and digestive gland samples (upper right), and their respective correlation with measured water concentration (below). For tissue sample $\mathrm{Cu}$ analysis,

females and males along PC1, with only little overlap (Fig. 4), implying a sex difference in expressions of most notably cat, $m t$, and $h s p 70$ (Table A.5).

\section{Linear (mixed) models}

In the full models, observed power was low for treatment effects $(<0.4)$ and treatment interactions $(<0.6)$ (Table A.3). Treatment effects were insignificant in all markers $(p>0.05)$, and only AChE showed an initially significant treatment interaction (Table A.3). Due to insignificance in a subsequent step of the AChE model selection, the treatment term was however excluded in all final models (Table 1). For $m t$ and $\mathrm{AChE}$, the final models were linear models separated by tissue, whereas the other markers were analyzed by linear mixed models. In cat, gst, GST, and $h s p 70$, there was a significant sex:tissue interaction, whereas sod expression only showed significant sex effects (Table 1). Significant sex effects were also observed in gill $m t$ expression and digestive gland $\mathrm{AChE}$ activity. In contrast, for $h s p 90$ expression, as well as $m t$ expression in digestive gland and $\mathrm{AChE}$ activity in gills, there

16 gill and 14 digestive gland samples remained after transcriptional and biochemical analyses. Circles represent single samples and black bars show group means

were no significant effects (Table 1). Males showed a significantly higher sod expression than females in general and a higher GST and AChE activity in gills and digestive gland, respectively. Females on the other hand displayed a significantly higher expression of $m t$ in gills, as well as a higher gillspecific expression of cat compared to males (Table 1). In addition, mean $h s p 70$ expression was higher in females than males, and the linear mixed model implied a sex:tissue interaction that was however not significantly confirmed post hoc (Table 1). Males displayed significantly higher relative cat and gst expressions in digestive gland as compared to gills, while females showed significantly higher GST activity in digestive gland as compared to gills (Table 1).

\section{Treatment effects}

Treatment effects were further analyzed in a simplified model of tissue-separated treatment effects, completely disregarding sex effects. One-way ANOVA analyses for each marker, separated by tissue, showed that no treatment response differed significantly from control. Observed power ranged from 
Fig. 2 Biomarker responses $\left(\log _{2}\right.$ fold-change relative control treatment) by copper treatment, in gill tissue ( $n=4$ per treatment) from A. anatina. Gray and white points correspond to gravid and nongravid mussels, respectively, while black bars show treatment median responses
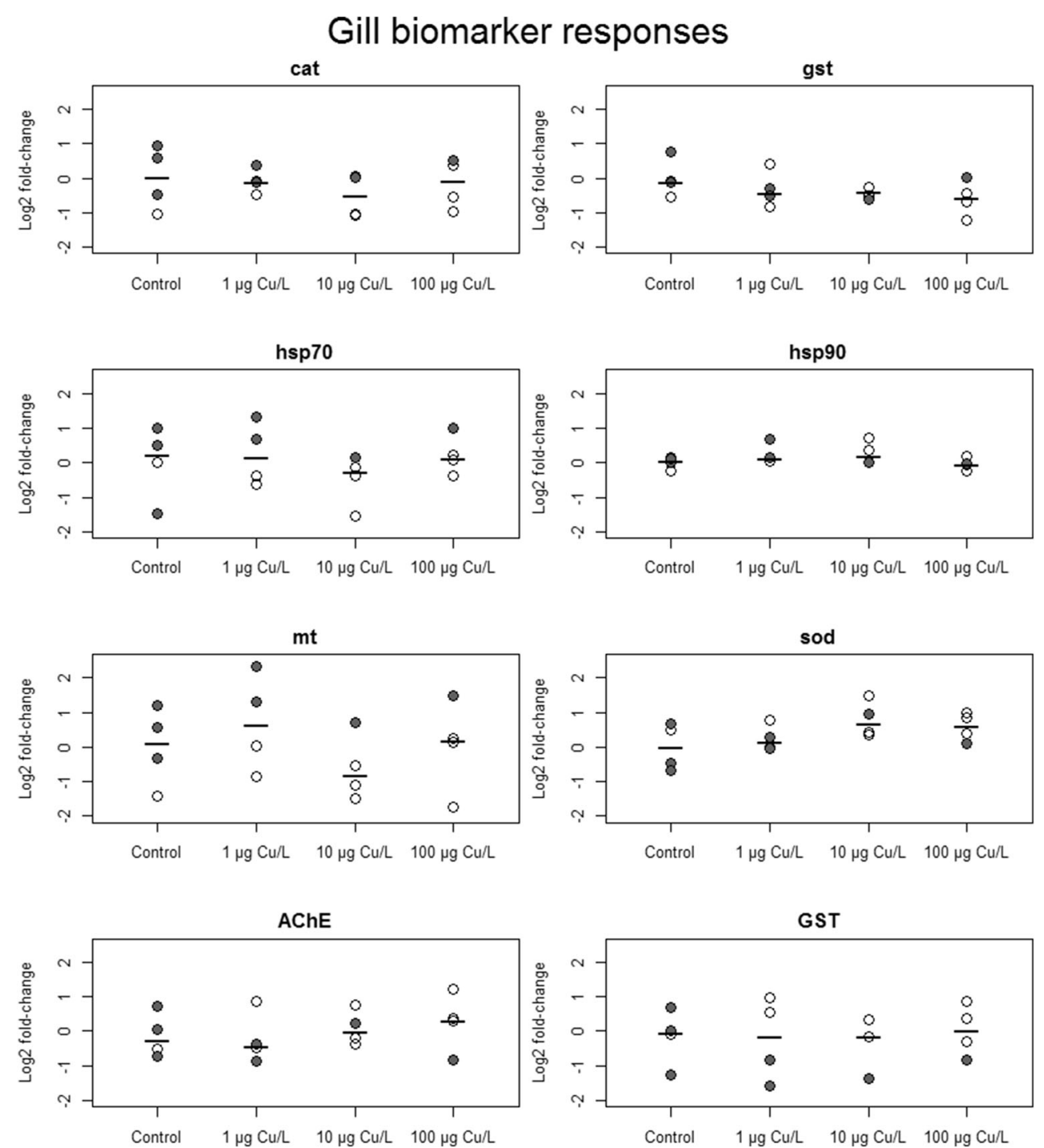

0.097 to 0.55 (Table A.6), and the largest observed mean response magnitudes for each marker ranged between a $\log _{2}$ fold-change of $0.26-0.80$ and $0.13-0.69$, in gills and digestive gland, respectively (Table A.6). For certain markers ( $h s p 90$ in gills, sod in gills and digestive gland, $\mathrm{AChE}$ in digestive gland), an approximate doubling of sample size would have given a power of 0.8 with current effect size, while others (e.g., cat and gst in digestive gland, GST in gills) would require more than a tenfold increase in sample size to achieve the requested power (Table A.6).

\section{Discussion}

\section{Cu exposure and uptake}

Bioavailability and potential uptake of $\mathrm{Cu}$ depends on various water parameters, and toxicity decreases with, for example, dissolved organic carbon (DOC) and water hardness (Arnold et al. 2009; Gillis et al. 2008, 2010; Wang et al. 2009; Giacomin et al. 2013). Importantly, bioavailability depends on $\mathrm{Cu}$ partitioning, which in turn is affected by both water parameters and sediment organic content (European Copper Institute 2008). For sandy sediments, Hassan et al. (1996) demonstrated $\mathrm{Cu}$ partition coefficients $\left(K_{d}\right)$ ranging from 0.6 to $149 \mathrm{~L} / \mathrm{kg}$, in line with estimated $K_{d}$ values from our experiment. Under current settings, the substrate is therefore assumed to be an important factor to reduce $\mathrm{Cu}$ bioavailability and potential stress responses, by adsorbing a major fraction of the added $\mathrm{Cu}$.

Different patterns of $\mathrm{Cu}$ uptake and tissue distribution have been reported for various bivalve species and exposure conditions (Canesi et al. 1999; García-Navarro et al. 2017; Nugroho and Frank 2011; Sakellari et al. 2013; Serafim and Bebianno 2009; Won et al. 2016). Whole-body BCFs of $3300 \mathrm{~L} / \mathrm{kg} \mathrm{WW}$ (Potipat et al. 2015) and 576 to approximately 
Fig. 3 Biomarker responses $\left(\log _{2}\right.$ fold-change relative control treatment) by copper treatment, in digestive gland tissue $(n=5$ per treatment) from A. anatina. Gray and white points correspond to gravid and non-gravid mussels, respectively, and black bars show treatment median responses
Digestive gland biomarker responses
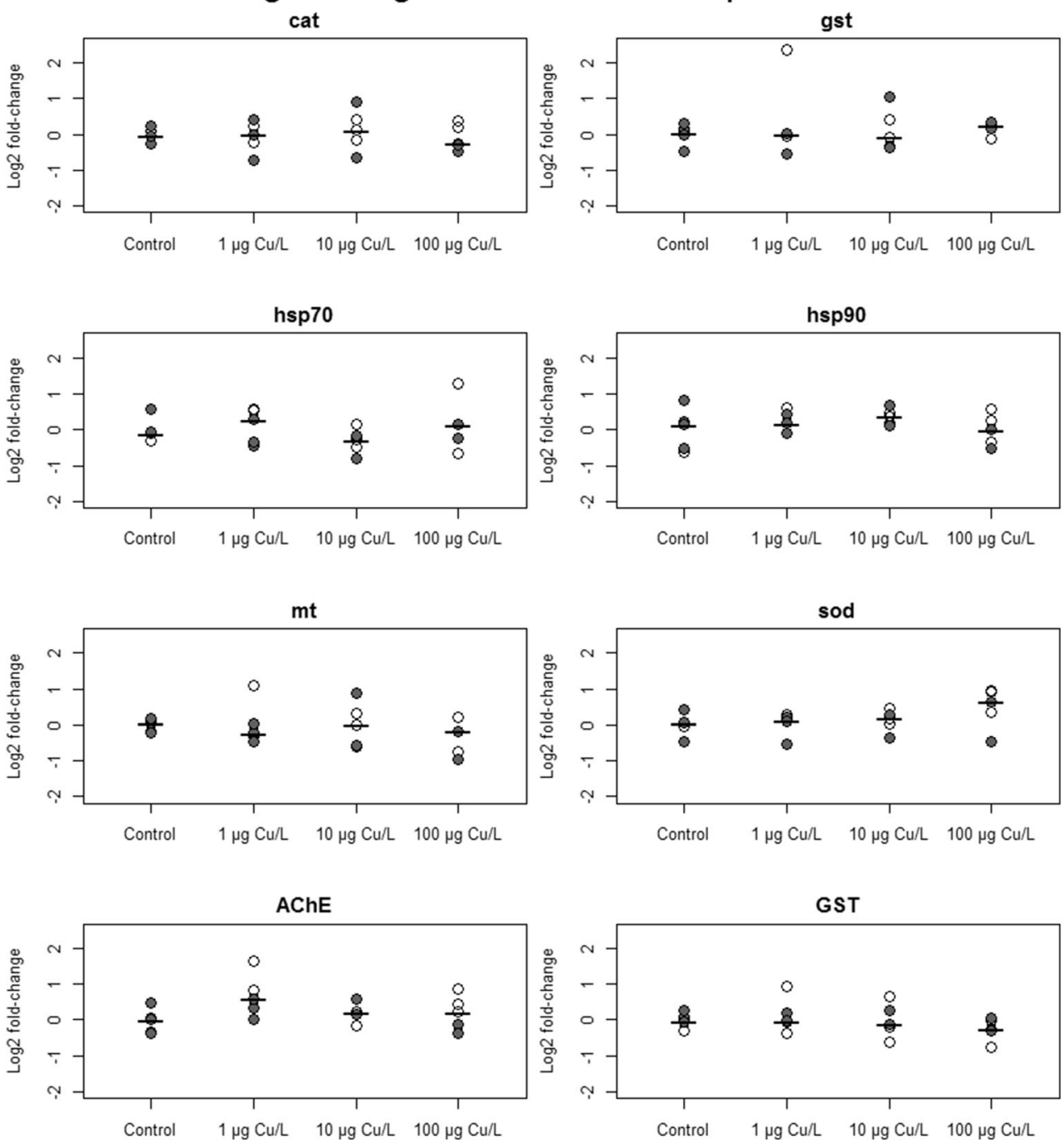

15,000 L/kg DW (Le et al. 2011; Rosioru et al. 2016) have been proposed. In gills specifically, a BCF of $42 \mathrm{~L} / \mathrm{kg}$ WW was modeled for Corbicula fluminea (Chen et al. 2010). For aquatic organisms in general, McGeer et al. (2003) reported a mean whole-body BCF of $1200 \pm 1800 \mathrm{~L} / \mathrm{kg} \mathrm{WW}$ under the exposure range of $1-10 \mu \mathrm{g} \mathrm{Cu} / \mathrm{L}$. Considering the variation in reported $\mathrm{Cu}$ uptake, our observed tissue concentrations and $\mathrm{BCF}$ are well within the expected range.

Under current settings, the gill $\mathrm{Cu}$ levels were positively correlated with water concentrations, implying $\mathrm{Cu}$ uptake under the highest exposures. Although treatment groups did not significantly differ in gill $\mathrm{Cu}$ concentrations, this is likely due to variation in actual exposure within and between groups. In contrast, digestive glands showed no correlation, suggesting that observed $\mathrm{Cu}$ concentrations rather reflect the tissue baseline. Potential, not necessarily mutually exclusive, explanations to differences between in gills and digestive glands include different accumulation and/ or elimination rates. Gills constitute a first-line defense against harmful toxicants, and gill uptake might be of importance for bivalve regulation of reactive oxygen species (ROS) under $\mathrm{Cu}$ stress (Won et al. 2016). However, fecal elimination, via the digestive gland, has been proposed as a major route for metal elimination in A. anatina (Nugroho and Frank 2011). At low exposure concentrations, an efficient $\mathrm{Cu}$ elimination might thus result in no net uptake to digestive glands. Also, accumulation rates may differ between tissues (Canesi et al. 1999; Serafim and Bebianno 2009). Thus, the current exposure period and/or $\mathrm{Cu}$ concentrations were potentially not enough for digestive gland net uptake to occur.

\section{Biomarker responses}

Experimental $\mathrm{Cu}$ exposures were in the lower range as compared to previous studies on bivalve transcriptional responses, and response magnitudes in our experiment were generally 


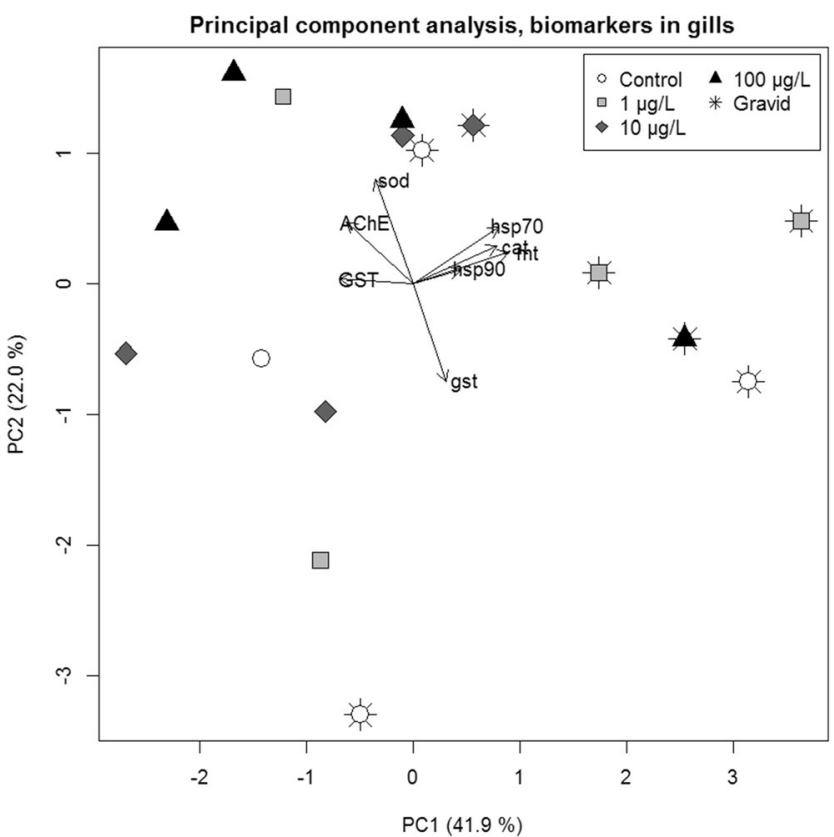

Fig. 4 Principal component analysis of eight molecular biomarker responses in gills of $A$. anatina $(n=16)$. Arrows imply the contribution of the respective biomarkers to $\mathrm{PC} 1$ and $\mathrm{PC} 2$

lower in both tissues than previously reported. All mean responses (converted back from the $\log _{2}$ scale) were within the range of $0.67-1.7$ relative to control. With regard to the biochemical markers, Mytilus galloprovincialis exposed for $96 \mathrm{~h}$ to 5 or $15 \mu \mathrm{g} \mathrm{Cu} / \mathrm{L}$ demonstrated an approximate 1.5 -fold increase in GST activity (Perić and Burić 2019). Similar to our results, AChE activity was however unaffected except in

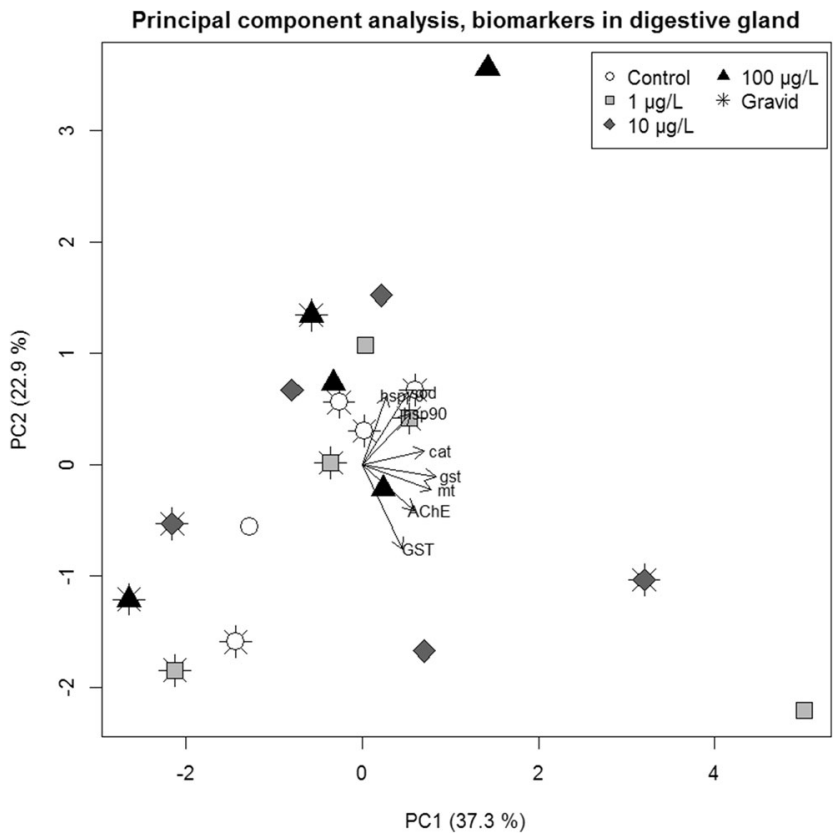

Fig. 5 Principal component analysis of eight molecular biomarker responses in digestive gland of $A$. anatina $(n=20)$. Arrows imply the contribution of the respective biomarkers to $\mathrm{PC} 1$ and $\mathrm{PC} 2$ a binary exposure of $\mathrm{Cu}$ and chlorpyrifos (Perić and Burić 2019). In contrast, in transcriptional markers, the freshwater mussel Corbicula fluminea displayed $\mathrm{mt}$, cat, sod, and gst responses varying between a tenfold decrease to a fourfold increase in gills and digestive gland after acute $(12 \mathrm{~h})$ exposure to a nominal concentration of $10 \mu \mathrm{g} \mathrm{Cu} / \mathrm{L}$ (Bigot et al. 2011). Our largest observed mean responses approximately correspond to acute $C$. fluminea response magnitudes at the nominal concentration of $50 \mu \mathrm{g} \mathrm{Cu} / \mathrm{L}$ (Bigot et al. 2011), however not regarding the same genes and tissues. Even larger response magnitudes have been demonstrated in, for example, larvae and hemocytes of Mytilus spp. after various $\mathrm{Cu}$ stress exposures. After exposure to $10-20 \mu \mathrm{g} \mathrm{Cu} / \mathrm{L}$, significant upregulations ranging between two- and eightfold increases have been demonstrated across all our assessed transcriptional markers (Boukadida et al. 2017; Liu et al. 2014, 2016). Without a treatment to serve as positive control, we currently cannot be certain of what level of $\mathrm{Cu}$ stress would be required to induce corresponding response magnitudes in A. anatina.

\section{Sex and tissue differences}

Except for AChE activity, digestive glands did not demonstrate sex-specific differences. Considering that no uptake was demonstrated for this tissue, for most of the tested biomarkers, there appears to be little sex influence on baseline signal. In contrast, gill signals differed distinctly in four markers, with females showing higher cat, $m t$, and $h s p 70$ (non-significant) expressions and lower GST activity than males. In A. anatina, gravidness develops sequentially from early summer until glochidia are released in late winter/early spring (Hinzmann et al. 2013). Since mussels were sampled in October, observed differences in gills could potentially be explained by gravidness, by the eggs and glochidia directly interfering with biomarker signals, and/or by protective molecular mechanisms in the gravid mussel gill. Acute toxicity (48 $\mathrm{h} \mathrm{LC}_{50}$ ) to A. anatina glochidia has been demonstrated at $18.9 \mu \mathrm{g} \mathrm{Cu} / \mathrm{L}$ (Kováts et al. 2010) and at 6.5-32 $\mu \mathrm{g} \mathrm{Cu} / \mathrm{L}$ in glochidia of various other unionid species (Wang et al. 2007). This range only overlaps the highest measured $\mathrm{Cu}$ concentrations of our experiment, whereas our mussels were exposed for a longer period. Still, we observed no treatment:sex:tissue interaction, suggesting that observed differences were mainly due to gravidness-induced baseline variation rather than responses to $\mathrm{Cu}$ exposure. Regardless of mechanistic explanation, relative sex differences in gills may possibly change over the course of the season depending on female gravidness.

In addition to tissue-specific sex differences, some markers showed a sex-specific difference in biomarker signal between tissues (cat, gst, GST). However, although $\mathrm{Cu}$ uptake patterns differed, no treatment:tissue or treatment:sex:tissue interaction was observed, i.e., no tissue difference in actual stress response can be concluded. In the absence of such interactions, 
Table 1 Effects from sex, tissue, and their interactions in the final (mixed) linear model for analyzed biomarkers, as well as the observed power for the effects (based on 100 simulations)

\begin{tabular}{|c|c|c|c|c|c|c|}
\hline Biomarker & Final model & (Fixed) effect & $\begin{array}{l}\text { Effect size } \\
\text { ( } \Delta \log _{2} \text { as } \\
\text { compared } \\
\text { to control) }\end{array}$ & $\begin{array}{l}\text { Obs. power } \\
(1-\beta)\end{array}$ & $\begin{array}{l}\text { Model term } \\
\text { sign. level }\end{array}$ & $\begin{array}{l}\text { Observed differences } \\
\text { (post hoc) }\end{array}$ \\
\hline \multirow[t]{4}{*}{ cat } & \multirow[t]{4}{*}{ Response $\sim$ Sex $*$ Tissue + (1|ID) } & Intercept (F:Dg) & -0.077 & - & - & \multirow{4}{*}{$\begin{array}{l}\text { Sex differences: } \\
\mathrm{Dg}: \mathrm{F}<\mathrm{M}(p=0.84) \\
G: F>M(p=0.0087) \\
\text { Tissue differences: } \\
\mathrm{F}: \mathrm{Dg}<\mathrm{G}(p=0.44) \\
M: D g>G(p=0.045)\end{array}$} \\
\hline & & Sex $(M: D g)$ & 0.17 & 0.32 & $p=0.089$ & \\
\hline & & Tissue (F:G) & 0.34 & 0.22 & $p=0.32$ & \\
\hline & & Sex:tissue (M:G) & -0.96 & 0.86 & $p=0.0061$ & \\
\hline \multirow[t]{5}{*}{ gst } & \multirow[t]{5}{*}{ Response $\sim$ Sex*Tissue $+(1 \mid$ ID $)$} & Intercept (F:Dg) & 0.060 & - & - & \multirow{5}{*}{$\begin{array}{l}\text { Sex differences: } \\
\mathrm{Dg}: \mathrm{F}<\mathrm{M}(p=0.73) \\
\mathrm{G}: \mathrm{F}>\mathrm{M}(p=0.31) \\
\text { Tissue differences: } \\
D g>G(p=0.0024) \\
\mathrm{F}: \mathrm{Dg}>\mathrm{G}(p=0.99) \\
M: D g>G(p=0.0009)\end{array}$} \\
\hline & & Sex (M:Dg) & 0.26 & 0.04 & $p=0.62$ & \\
\hline & & Tissue $(\mathrm{F}: \mathrm{G})$ & -0.060 & 0.94 & $p=0.0020$ & \\
\hline & & Sex:tissue (M:G) & -0.74 & 0.82 & $p=0.0067$ & \\
\hline & & & & & & \\
\hline \multirow[t]{5}{*}{ hsp 70} & \multirow[t]{5}{*}{ Response $\sim$ Sex $*$ Tissue $+(1 \mid$ ID $)$} & Intercept (F:Dg) & -0.11 & - & - & \multirow{5}{*}{$\begin{array}{l}\text { Sex differences: } \\
\text { Dg:F < M }(p=0.86) \\
\text { G:F }>\mathrm{M}(p=0.067) \\
\text { Tissue differences: } \\
\mathrm{F}: \mathrm{Dg}<\mathrm{G}(p=0.25) \\
\mathrm{M}: \mathrm{Dg}>\mathrm{G}(p=0.39)\end{array}$} \\
\hline & & Sex $(M: D g)$ & 0.21 & 0.12 & $p=0.28$ & \\
\hline & & Tissue $(\mathrm{F}: \mathrm{G})$ & 0.56 & 0.05 & $p=0.84$ & \\
\hline & & Sex:tissue (M:G) & -1.0 & 0.79 & $p=0.021$ & \\
\hline & & & & & & \\
\hline hsp 90 & Response $\sim(1 \mid \mathrm{ID})$ & Intercept & 0.15 & - & - & - \\
\hline \multirow[t]{3}{*}{$m t$} & Gill response $\sim$ Sex +1 & Intercept $(\mathrm{F})$ & 1.0 & - & - & \multirow{2}{*}{$\begin{array}{l}\text { Sex difference: } \\
F>M(p=0.00051)\end{array}$} \\
\hline & & $\operatorname{Sex}(M)$ & -1.8 & 0.99 & $p=0.00051$ & \\
\hline & Dig. gland response $\sim 1$ & Intercept & -0.086 & - & - & - \\
\hline \multirow[t]{2}{*}{ sod } & Response $\sim \operatorname{Sex}+(1 \mid \mathrm{ID})$ & Intercept $(\mathrm{F})$ & 0.054 & - & - & \multirow{2}{*}{$\begin{array}{l}\text { Sex difference: } \\
F<M(p=0.012)\end{array}$} \\
\hline & & $\operatorname{Sex}(\mathrm{M})$ & 0.44 & 0.75 & $p=0.011$ & \\
\hline \multirow[t]{3}{*}{$\mathrm{AChE}$} & Gill response $\sim 1$ & Intercept & 0.0083 & - & - & - \\
\hline & Dig. gland response $\sim \mathrm{Sex}+1$ & Intercept $(\mathrm{F})$ & 0.088 & - & - & \multirow{2}{*}{$\begin{array}{l}\text { Sex difference: } \\
F<M(p=0.049)\end{array}$} \\
\hline & & $\operatorname{Sex}(M)$ & 0.43 & 0.56 & $p=0.049$ & \\
\hline \multirow[t]{5}{*}{ GST } & Response $\sim$ Sex $*$ Tissue $+(1 \mid$ ID $)$ & Intercept (F:Dg) & 0.022 & - & - & \multirow{5}{*}{$\begin{array}{l}\text { Sex differences: } \\
\mathrm{Dg}: \mathrm{F}>\mathrm{M}(p=0.95) \\
G: F<M(p=0.0031) \\
\text { Tissue differences: } \\
F: D g>G(p=0.025) \\
\mathrm{M}: \mathrm{Dg}<\mathrm{G}(p=0.39)\end{array}$} \\
\hline & & Sex $(M: D g)$ & -0.13 & 0.49 & $p=0.066$ & \\
\hline & & Tissue (F:G) & -0.76 & 0.19 & $p=0.29$ & \\
\hline & & Sex:tissue (M:G) & 1.1 & 0.89 & & \\
\hline & & & & & & \\
\hline
\end{tabular}

Significance level is presented for all model terms, and differences were tested post hoc for significant model terms $(p<0.05)$. Italicized entries imply observed powers $\geq 0.8$ and $p$ values $<0.05$. $D g$ digestive gland, $G$ gills, $F$ females, $M$ males

remaining tissue differences rather reflect overall variation within and between sexes.

\section{Tested biomarkers}

The currently tested biomarkers represent a subset of general stress responses and have all previously been shown to respond to $\mathrm{Cu}$ exposure in bivalves (Bigot et al. 2011; Boukadida et al. 2017; Goswami et al. 2014; Liu et al. 2014, 2016; Perić et al. 2017). Apart from metallothionein, which is cytoprotective by binding to metals (Fabisiak et al. 1999), the biomarkers were however not expected to respond specifically to $\mathrm{Cu}$ exposure.
Rather, responses would mainly reflect mechanisms of cellular protection from, for example, oxidative stress (Bigot et al. 2011; Boukadida et al. 2017) or protein damage (Liu et al. 2014, 2016). The primary objective was to identify biomarkers responding to general chemical stress in A. anatina, rather than to respond specifically to $\mathrm{Cu}$ exposure. Since we failed to detect stress responses at current elevated $\mathrm{Cu}$ concentrations, additional markers, specific to $\mathrm{Cu}$ or other target pollutants, might be needed before $A$. anatina can be successfully used in, for example, environmental monitoring.

An ideal biomarker for early warnings of chemical stress should be one that gives a strong response at levels below, or 
time points before, responses translate to whole-organism effects. Despite low exposure concentrations, $\mathrm{Cu}$ in our experiment was approaching water levels at which we previously observed prolonged shell closure in preliminary experiments (unpublished). That is, further concentration increases would risk higher-level effects by affecting mussel behavior. In practice, the window for detecting early warnings might thus be quite narrow for acute $\mathrm{Cu}$ stress, further increasing the need of a strong biomarker response.

In our experiment, response magnitudes were generally small, but an approximate doubling of the sample size would have substantially increased the power for $h s p 90$, sod, and $\mathrm{AChE}$ in one or both tissues. However, most of the markers would require drastically increased sample sizes to improve power. Ideally, large effects should be obtained biologically by high response magnitude and/or statistically by low natural variation, even at small sample sizes. At current $\mathrm{Cu}$ stress, A. anatina background variation however obscures potential low-magnitude responses, and the tested markers appear to require quite drastically increased sample sizes for detection of early warnings. Thus, no successful A. anatina biomarker candidate can be singled out, and further search for and/or evaluation of biomarkers is necessary Alternatively, successful assessment of low-level stress may ultimately depend on response pattern analysis of multiple stress biomarkers.

\section{Conclusion}

Either larger response magnitudes or substantially larger sample sizes would have been required to quantify molecular stress responses under the current $\mathrm{Cu}$ concentrations. Our results, specifically displayed by sex differences in gills, illustrate how potential low-magnitude stress responses, and potentially early warnings, might be obscured by variations in baseline biomarker expression/activity. However, for successful development of environmentally relevant biomarker models, natural variation should preferably be addressed rather than avoided. Being abundant, sessile, and ecologically relevant, we suggest further studies on Anodonta anatina as a biomarker model species. A better understanding of response magnitudes, variation, and links to higher biological levels is needed to realize the potential of A. anatina as a freshwater biomarker model.

Acknowledgments Open access funding provided by Lund University. We thank Sofia Mebrahtu Wisén of the Stable Isotope Service Lab, Department of Biology, Lund University (www.biology.lu.se/services/ instrumental-chemistry), for performing the chemical water analysis. We also thank Håkan Björklund for initial help with species determination. The work was carried out in accordance with Swedish legislation and mussels were collected in agreement with the fishing holder of Vinne å. Exposure treatments, RNA extraction, cDNA synthesis, qPCR assay efficiency determination, and biochemical assays were performed in the ALS Scandinavia Toxicon AB laboratory facilities, while RNA fragment analysis and qPCR assays were performed at
TATAA Biocenter. Robert Sjöback of TATAA Biocenter was involved in the design of primers and qPCR assays, as well as in methodological evaluation. Tissue sample $\mathrm{Cu}$ concentrations were analyzed by the ALS Scandinavia laboratory in Luleå, Sweden.

Funding information This research was supported by the Swedish Knowledge Foundation and co-funded by ALS Scandinavia Toxicon AB (Landskrona, Sweden) and TATAA Biocenter (Gothenburg, Sweden).

\section{Compliance with ethical standards}

Conflict of interest This study is part of the project WaterAssess, which is a collaboration between University of Skövde, Lund University, ALS Scandinavia Toxicon AB, and TATAA Biocenter, and the work is partially funded by commercial companies (ALS Scandinavia Toxicon AB, Landskrona, Sweden, and TATAA Biocenter, Gothenburg, Sweden). Project outlines have been determined jointly, but experimental design and data analysis was carried out largely without involvement of the funding sources. Where present, commercial interests have been judged not to bias the scientific. Gustaf Ekelund Ugge is employed by ALS Scandinavia Toxicon AB, but is currently on a leave of absence for pursuing a PhD. Robert Sjöback is employed and in the board of TATAA Biocenter

Open Access This article is licensed under a Creative Commons Attribution 4.0 International License, which permits use, sharing, adaptation, distribution and reproduction in any medium or format, as long as you give appropriate credit to the original author(s) and the source, provide a link to the Creative Commons licence, and indicate if changes were made. The images or other third party material in this article are included in the article's Creative Commons licence, unless indicated otherwise in a credit line to the material. If material is not included in the article's Creative Commons licence and your intended use is not permitted by statutory regulation or exceeds the permitted use, you will need to obtain permission directly from the copyright holder. To view a copy of this licence, visit http://creativecommons.org/licenses/by/4.0/.

\section{References}

Aldridge DC (1999) The morphology, growth and reproduction of Unionidae (Bivalvia) in a fenland waterway. J Molluscan Stud 65: 47-60

Álvarez-Vázquez MA, Prego R, Caetano M, De Uña-Álvarez E, Doval M, Calvo S, Vale C (2017) Contributions of trace elements to the sea by small uncontaminated rivers: effects of a water reservoir and a wastewater treatment plant. Chemosphere 178:173-186

Arnold WR, Cotsifas JS, Smith DS, Le Page S, Gruenthal KM (2009) Comparison of the copper sensitivity of two economically important saltwater mussel species and a review of previously reported copper toxicity data for mussels: important implications for determining future ambient copper saltwater criteria in the USA. Environ Toxicol 24(6):618-628

Bahamonde PA, Feswick A, Isaacs MA, Munkittrick KR, Martyniuk CJ (2016) Defining the role of omics in assessing ecosystem health: perspectives from the Canadian environmental monitoring program. Environ Toxicol Chem 35(1):20-35

Barnhart MC, Haag WR, Roston WN (2008) Adaptations to host infection and larval parasitism in Unionoida. J N Am Benthol Soc 27(2): 370-394

Bates D, Maechler M, Bolker B, Walker S (2015) Fitting linear mixedeffects models using lme4. J Stat Softw 67(1):1-48 
Bhuiyan MAH, Dampare SB, Islam MA, Suzuki S (2015) Source apportionment and pollution evaluation of heavy metals in water and sediments of Buriganga River, Bangladesh, using multivariate analysis and pollution evaluation indices. Environ Monit Assess 187: 4075

Bielen A, Bošnjak I, Sepčić K, Jaklič M, Cvitanić M, Lušić J, Lajtner J, Simčič T, Hudina S (2016) Differences in tolerance to anthropogenic stress between invasive and native bivalves. Sci Tot Environ 543: 449-459

Bigot A, Minguez L, Giambérini L, Rodius F (2011) Early defense responses in the freshwater bivalve Corbicula fluminea exposed to copper and cadmium: transcriptional and histochemical studies. Environ Toxicol 26:623-632

Binelli A, Della Torre C, Magni S, Parolini M (2015) Does zebra mussel (Dreissena polymorpha) represent the freshwater counterpart of Mytilus in ecotoxicological studies? A critical review. Environ Pollut 196:386-403

Bocquené G, Galgani F (1998) Biological effects of contaminants: cholinesterase inhibition by organophosphate and carbamate compounds In: ICES Techniques in marine environmental sciences 22

Boukadida K, Cachot J, Clérandeaux C, Gourves PY, Banni M (2017) Early and efficient induction of antioxidant defense system in Mytilus galloprovincialis embryos exposed to metals and heat stress. Ecotox Environ Safe 138:105-112

Bradford MM (1976) A rapid and sensitive method for quantitation of microgram quantities of protein utilizing the principle of protein dye binding. Anal Biochem 72:248-254

Canesi L, Viarengo A, Leonzio C, Filippelli M, Gall G (1999) Heavy metals and glutathione metabolism in mussel tissues. Aquat Toxicol 46:67-76

Champely S (2018) pwr: basic functions for power analysis. R package version 1:2-2. https://CRAN.R-project.org/package=pwr

Chen WY, Lin CM, Ju YR, Liao CM (2010) A simple allometric diffusion-based biokinetic model to predict $\mathrm{Cu}$ (II) uptake across gills of freshwater clam Corbicula fluminea. Bull Environ Contam Toxicol 84:703-707

Connon RE, Geist J, Werner I (2012) Effect-based tools for monitoring and predicting the ecotoxicological effects of chemicals in the aquatic environment. Sensors 12:12741-12771

Core Team R (2018) R: a language and environment for statistical computing. R Foundation for Statistical Computing, Vienna https:// www.R-project.org/

Engström E, Stenberg A, Senioukh S, Edelbro R, Baxter DC, Rodushkin I (2004) Multi-elemental characterization of soft biological tissues by inductively coupled plasma-sector field mass spectrometry. Anal Chim Acta 521:123-135

European Copper Institute (2008) European Union Risk Assessment Report. Voluntary risk assessment of copper, copper II sulphate pentahydrate, copper(I)oxide, copper(II)oxide, dicopper chloride trihydroxide. Chapter 3 - Environmental Exposure. Appendix F Partitioning coefficient water-sediment

Fabisiak JP, Tyurin VA, Tyurina YY, Borisenkto GG, Korotaeva A, Pitt BR, Lazo JS, Kagan VE (1999) Redox regulation of copper-metallothionein. Arch Biochem Biophys 363(1):171-181

Falfushynska HI, Gnatyshyna LL, Stoliar OB (2013) Effect of in situ exposure history on the molecular responses of freshwater bivalve Anodonta anatina (Unionidae) to trace metals. Ecotox Environ Safe 89:73-83

Falfushynska HI, Gnatyshyna LL, Gyori J, Stoliar OB (2014) Metallothioneins, caspase- 3 and oxidative stress responses in the multi-marker study of freshwater mussel inhabiting sites of various human impact. Turk J Fish Aquat Sc 14:591-603

Fent K, Sumpter JP (2011) Progress and promises in toxicogenomics in aquatic toxicology: is technical innovation driving scientific innovation? Aquat Toxicol 105S:25-39
García-Navarro JA, Franco L, Romero D (2017) Differences in the accumulation and tissue distribution of $\mathrm{Pb}, \mathrm{Cd}$, and $\mathrm{Cu}$ in Mediterranean mussels (Mytilus galloprovincialis) exposed to single, binary, and ternary metal mixtures. Environ Sci Pollut Res 24:6599-6610

Giacomin M, Gillis PL, Bianchini A, Wood CM (2013) Interactive effects of copper and dissolved organic matter on sodium uptake, copper bioaccumulation, and oxidative stress in juvenile freshwater mussels (Lampsilis siliquoidea). Aquat Toxicol 144-145:105-115

Gillis PL, Mitchell RJ, Schwalb AN, McNichols KA, Mackie GL, Wood CM, Ackerman JD (2008) Sensitivity of the glochidia (larvae) of freshwater mussels to copper: assessing the effect of water hardness and dissolved organic carbon on the sensitivity of endangered species. Aquat Toxicol 88:137-145

Gillis PL, McGeer JC, Mackie GL, Wilkie MP, Ackerman JD (2010) The effect of natural dissolved organic carbon on the acute toxicity of copper to larval freshwater mussels (glochidia). Environ Toxicol Chem 29(11):2519-2528

Gonzales-Rey M, Mattos JJ, Piazza CE, Bainy ACD, Bebianno MJ (2014) Effects of active pharmaceutical ingredients mixtures in mussel Mytilus galloprovincialis. Aquat Toxicol 153:12-26

Goswami P, Hariharan G, Godhantaraman N, Munuswamy N (2014) An integrated use of multiple biomarkers to investigate the individual and combined effect of copper and cadmium on the marine green mussel (Perna viridis). J Environ Sci Heal A 49:1564-1577

Green P, MacLeod CJ (2016) simr: an R package for power analysis of generalised linear mixed models by simulation. Methods Ecol Evol 7(4):493-498

Habig WH, Pabst MJ, Jakoby B (1974) Glutathione-S-transferase. The first enzymatic step in mercapturic acid formation. J Biol Chem 249: $7130-7139$

Hartmann JT, Beggel S, Auerswald K, Stoeckle BC, Geist J (2016) Establishing mussel behavior as a biomarker in ecotoxicology. Aquat Toxicol 170:279-288

Hassan SM, Garrison AW, Allen HE, Di Toro DM, Ankley GT (1996) Estimation of partition coefficients for five trace metals in sandy sediments and application to sediment quality criteria. Environ Toxicol Chem 15(12):2198-2208

Havs- och vattenmyndigheten (2018) HVMFS 2013:19. Klassificering och miljökvalitetsnormer avseende ytvatten. Revised in HVMFS 2018:17

Hinzmann M, Lopes-Lima M, Teixeira A, Varandas S, Sousa R, Lopes A, Froufe E, Machado J (2013) Reproductive cycle and strategy of Anodonta anatina (L., 1758): notes on hermaphroditism. J Exp Zool 9999:1-13

International organization for standardization (2012) ISO 6341:2012. Water quality - determination of the inhibition of the mobility of Daphnia magna Straus (Cladocera, Crustacea) - acute toxicity test. Fourth edition 2012-10-15

Jaumot J, Navarro A, Faria M, Barata C, Tauler R, Piña B (2015) qRTPCR evaluation of the transcriptional response of zebra mussel to heavy metals. BMC Genomics 16:354

Jonsson A, Bertilsson A, Rydgård M (2013) Spatial distribution and age structure of the freshwater unionid mussels Anodonta anatina and Unio tumidus: implications for environmental monitoring. Hydrobiologia 711:61-70

Kassambara A, Mundt F (2017) factoextra: extract and visualize the results of multivariate data analyses. R package version 1.0.5. https:// CRAN.R-project.org/package=factoextra

Kováts N, Abdel-Hameid NA, Kovács K, Paulovits G (2010) Sensitivity of three unionid glochidia to elevated levels of copper, zinc and lead. Knowl Manag Aquat Ec 399:04

Le TTY, Leuven RSEW, Hendriks AJ (2011) Modeling metal bioaccumulation in the invasive mussels Dreissena polymorpha and Dreissena rostiformis bugensis in the rivers Rhine and Meuse. Environ Toxicol Chem 30(12):2825-2830 
Lehtonen KK, Turja R, Budzinski H, Devier MH (2016) An integrated chemical-biological study using caged mussles (Mytilus trossulus) along a pollution gradient in the Archipelago Sea (SW Finland, Baltic Sea). Mar Environ Res 119:207-221

Lenth R (2018) emmeans: estimated marginal means, aka least-squares means. R package version 1.2.4. https://CRAN.R-project.org/ package $=$ emmeans

Liu H, He J, Chi C, Shao J (2014) Differential HSP70 expression in Mytilus coruscus under various stressors. Gene 543:166-173

Liu H, Wu J, Xu M, He J (2016) A novel biomarker for marine environmental pollution of HSP90 from Mytilus coruscus. Mar Pollut Bull 111:428-434

Livak KJ, Schmittgen TD (2001) Analysis of relative gene expression data using real-time quantitative PCR and the $2^{-\Delta \Delta C T}$ method. Methods 25:402-408

Lopes-Lima M (2014) Anodonta anatina. The IUCN Red List of Threatened Species 2014: e.T155667A21400363. https://doi.org/ 10.2305/IUCN.UK.2014-1.RLTS.T155667A21400363.en. Accessed on October 31st 2019

Lüdecke D (2018) sjstats: statistical functions for regression models. R package version 0.17.0. https://CRAN.R-project.org/package $=$ sjstats

Lurman G, Walter J, Hoppeler HH (2014) Seasonal changes in the behaviour and respiration physiology of the freshwater duck mussel, Anodonta anatina. J Exp Biol 217:235-243

McGeer JC, Brix KV, Skeaff JM, Deforest DK, Brigham SI, Adams WJ, Green A (2003) Inverse relationship between bioconcentration factor and exposure concentration for metals: implications for hazard assessment of metals in the aquatic environment. Environ Toxicol Chem 22(5):1017-1037

Navarro A, Faria M, Barata C, Piña B (2011) Transcriptional response of stress genes to metal exposure in zebra mussel larvae and adults. Environ Pollut 159:100-107

Nugroho AP, Frank H (2011) Uptake, distribution, and bioaccumulation of copper in the freshwater mussel Anodonta anatina. Toxicol Environ Chem 93(9):1838-1850

Nugroho AP, Frank H (2012a) Effects of copper exposure on calcium, carbohydrate, and protein levels in the freshwater mussel Anodonta anatina. Toxicol Environ Chem 94(1):99-108

Nugroho AP, Frank H (2012b) Effects of copper on lipid peroxidation, glutathione, metallothionein, and antioxidative enzymes in the freshwater mussel Anodonta anatina. Toxicol Environ Chem 94(5):918-929

Oliviera P, Lopes-Lima M, Machado J, Guilhermino L (2015) Comparative sensitivity of European native (Anodonta anatina) and exotic (Corbicula fluminea) bivalves to mercury. Estuar Coast Shelf S 167:191-198

Organisation for Economic Co-operation and Development (1992) OECD guideline for the testing of chemicals. Test No. 203: Fish, acute toxicity test. Third edition 1992-07-17

Organisation for Economic Co-operation and Development (2004) OECD guideline for the testing of chemicals. Test No. 202: Daphnia sp., acute immobilization test. Third edition 2004-04-13

Organisation for Economic Co-operation and Development (2006) OECD guideline for the testing of chemicals. Test No. 201: Freshwater alga and cyanobacteria, growth inhibition test. Third edition 2006-03-23, corrected 2011-07-28

Organisation for Economic Co-operation and Development (2012) OECD guideline for the testing of chemicals. Test No. 211: Daphnia magna reproduction test. Third edition 2012-10-02
Perić L, Burić P (2019) The effect of copper and chlorpyrifos co-exposure on biomarkers in the marine mussel Mytilus galloprovincialis. Chemosphere 225:126-134

Perić L, Nerlović V, Žurga P, Žilić L, Ramšak A (2017) Variations of biomarkers response in mussels Mytilus galloprovincialis to low, moderate and high concentrations of organic chemicals and metals. Chemosphere 174:554-562

Potipat J, Tangkrock-olan N, Helander HF (2015) Bioconcentration factor (BCF) and depuration of heavy metals of oysters (Saccostrea cucullata) and mussels (Perna viridis) in the river basins of coastal area of Chanthaburi province, gulf of Thailand. Environment Asia $8(2): 118-128$

Rosioru DM, Oros A, Lazar L (2016) Assessment of the heavy metals contamination in bivalve Mytilus galloprovincialis using accumulation factors. J Environ Prot Ecol 17(3):874-884

Sakellari A, Karavoltsos S, Theodorou D, Dassenakis M, Scoullos M (2013) Bioaccumulation of metals $(\mathrm{Cd}, \mathrm{Cu}, \mathrm{Zn})$ by the marine bivalves M. galloprovincialis, P. radiata, V. verrucosa and C. chione in Mediterranean coastal microenvironments: association with metal bioavailability. Environ Monit Assess 185:3383-3395

Sander SG, Anderson B, Reid MR, Kim JP, Hunter KA (2013) Trace metal chemistry in the pristine freshwater Lake Hauroko, Fiordland, New Zealand. Microchem J 111:74-81

Santini O, Chahbane N, Vasseur P, Frank H (2011) Effects of low-level copper exposure on $\mathrm{Ca}^{2+}$-ATPase and carbonic anhydrase in the freshwater bivalve Anodonta anatina. Toxicol Environ Chem 93(9):1826-1837

Serafim A, Bebianno MJ (2009) Metallothionein role in the kinetic model of copper accumulation and elimination in the clam Ruditapes decussatus. Environ Res 109:390-399

Vukosav P, Mlakar M, Cukrov N, Kwokal Ž, Pižeta I, Pavlus N, Špoljarić I, Vurnek M, Brozinčević A, Omanović D (2014) Heavy metal contents in water, sediment and fish in a karst aquatic ecosystem of the Plitvice Lakes National Park (Croatia). Environ Sci Pollut Res 21:3826-3839

Wang N, Ingersoll CG, Hardesty DK, Ivey CD, Kunz JL, May TW, Dwyer FJ, Roberts AD, Augspurger T, Kane CM, Neves RJ, Barnhart MC (2007) Acute toxicity of copper, ammonia, and chlorine to glochidia and juveniles of freshwater mussels (Unionidae). Environ Toxicol Chem 26:2036-2047

Wang N, Mebane CA, Kunz JL, Ingersoll CG, May TW, Arnold WR, Santore RC, Augspurger T, Dwyer FJ, Barnhart MC (2009) Evaluation of acute copper toxicity to juvenile freshwater mussels (fatmucket, Lampsilis siliquoidea) in natural and reconstituted waters. Environ Toxicol Chem 28(11):2367-2377

Wilson JG, McMahon RF (1981) Effects of high environmental copper concentration on the oxygen consumption, condition and shell morphology of natural populations of Mytilus edulis L. and Littorina rudis maton. Comp Biochem Physiol 70C:139-147

Won EJ, Kim KT, Choi JY, Kim ES, Ra K (2016) Target organs of the Manila clam Ruditapes philippinarum for studying metal accumulation and biomarkers in pollution monitoring: laboratory and in-situ transplantation experiments. Environ Monit Assess 188:478

Publisher's note Springer Nature remains neutral with regard to jurisdictional claims in published maps and institutional affiliations. 